\title{
Percutaneous coronary interventions in cardiac allograft vasculopathy - a case report and review of the literature
}

\author{
Jozica Šikić, \\ Dario Gulin*, \\ Edvard Galić, \\ Jasna Čerkez Habek \\ University Hospital "Sveti \\ Duh", Zagreb, Croatia
}

RECEIVED:

February 9, 2016

ACCEPTED:

February 20, 2016

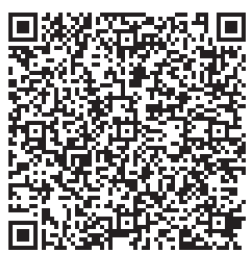

$\square$ Cardiologia Croatica 2016;11(3-4):108
KEYWORDS: heart transplantation, arteriosclerosis, coronary balloon.

CITATION: Cardiol Croat. 2016;11(3-4):108. | DOI: http://dx.doi.org/10.15836/ccar2016.108

*ADDRESS FOR CORRESPONDENCE: Dario Gulin, Klinička bolnica Sveti Duh, Sveti Duh 64, HR-10000 Zagreb, Croatia. / Phone: +385-91-337-5484 / E-mail: dariogulin@gmail.com

ORCID: Jozica Šikić, http://orcid.org/0000-0003-4488-0559 • Dario Gulin, http://orcid.org/0000-0001-8502-7816 Edvard Galić, http://orcid.org/0000-0002-5707-0961 • Jasna Čerkez Habek, http://orcid.org/0000-0003-3177-3797

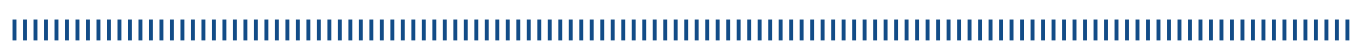

Introduction: Cardiac allograft vasculopathy (CAV) is a challenging long-term complication of cardiac transplantation and remains a leading long-term cause of graft failure, re-transplantation, and death. ${ }^{1-3}$ Not only pathological characteristics, but also asymptomatic presentation of CAV is significantly different from typical atherosclerotic coronary artery disease (CAD). Large multicenter studies of heart transplant recipients undergoing percutaneous coronary interventions are lacking.

Case report: 65-year-old male patient, with prior history of heart transplantation in 2010, was admitted to hospital in October 2014 due to routine annually cardiac testing. Previously performed coronary angiographies showed no significant coronary artery disease. His recent cardiac history was unremarkable. Coronary angiography revealed significant stenosis in middle part of left anterior descending artery (LAD) which was treated with drug-eluting balloon (DEB - paclitaxel). A year and a half later no progression of LAD stenosis was observed.

Discussion: CAV is a multifactorial process in which the immune system presents the driving force. Cells from the innate and the adaptive system cooperate to reject the foreign heart which results in endothelial dysfunction and migration and proliferation of smooth muscle cells. This process, as opposed to atherosclerosis is very fast, usually lasting few months to complete vascular occlusion. Previous studies about drug-eluting stents (everolimus or sirolimus) and bare-metal stents in treating CAV show no significant difference in target lesion revascularisation rate. Studies with bioresorbable scaffolds are currently being conducted. There are no studies showing concomitant long term use of antiplatelet, especially ticagrelor and prasugrel, and immunosuppressive therapy. Due to our knowledge studies using DEB in CAV have not been performed. As it requires short-term antiplatelet therapy and provides optimised homogenous drug dispersion it could provide optimal treatment of CAV.

LITERATURE IIIIIIIIIIIIIIIIIIIIIIIIIIIIIIIIIIIIIIIIIIIIIIIIIIIIIIIIIIIIIIIIIIIIIIIIIIIIIIIIIIIIIIIIIIIIIIIIIIIIIIII

1. Payne GA, Hage FG, Acharya D. Transplant allograft vasculopathy: Role of multimodality imaging in surveillance and diagnosis. J Nucl Cardiol. 2015 Dec 28. [Epub ahead of print]. DOI: http://dx.doi.org/10.1007/s12350-015-0373-3

2. Stehlik J, Edwards LB, Kucheryavaya AY, Aurora P, Christie JD, Kirk R, et al. The Registry of the International Society for Heart and Lung Transplantation: twenty-seventh official adult heart transplant report--2010. J Heart Lung Transplant. 2010;29(10):1089-103. DOI: http://dx.doi.org/10.1016/j.healun.2010.08.007

3. Costanzo MR, Dipchand A, Starling R, Anderson A, Chan M, Desai S, et al; International Society of Heart and Lung Transplantation Guidelines. The International Society of Heart and Lung Transplantation Guidelines for the care of heart transplant recipients. J Heart Lung Transplant. 2010;29(8):914-56. DOI: http://dx.doi.org/10.1016/j.healun.2010.05.034 